\title{
3 Research Square

\section{Protective Potential of Adiponectin and Quercetin on Alleviating Bisphenol-A-Induced Toxicity in Muscle Cells Through the KEAP1/NRF2 Pathway}

\section{Davood Mohammadi}

Zanjan University of Medical Sciences

Farideh Jalali-Mashayekhi

Arak University of Medical Sciences

Keivan Nedaei

Zanjan University of Medical Sciences

Darya Ghadimi

Zanjan University of Medical Sciences

Zahra Rasooli

Zanjan University of Medical Sciences

Mina Hemmati ( $\nabla$ mina1hemmati@yahoo.com )

Zanjan University of Medical Sciences https://orcid.org/0000-0001-9401-5067

\section{Research Article}

Keywords: BPA, Adiponectin, Quercetin, Nrf2 / KEAP1, Muscle cell

Posted Date: December 28th, 2021

DOI: https://doi.org/10.21203/rs.3.rs-1169857/v1

License: (c) (i) This work is licensed under a Creative Commons Attribution 4.0 International License.

Read Full License 


\section{Abstract}

Background: Bisphenol A (BPA) is a toxic environmental estrogenic compound which exerts its detrimental effects by increasing oxidative stress and decreasing levels of antioxidants. This study aimed to evaluate beneficial effect of adiponectin and quercetin in reducing BPA-induced oxidative stress by assessing the Prooxidant-antioxidant balance (PAB) assay, catalase activity and KEAP1/NRF2 expression in muscle cells.

Methods and Results: L6 rat muscle cells were exposed to BPA (50 an100 $\mu \mathrm{M})$ with and without treatment with different concentrations of adiponectin $(10$ and $100 \mathrm{ng} / \mathrm{ml})$ and quercetin $(10$ and 25 $\mathrm{ng} / \mathrm{ml}$ ) for 24 and 48 hours. Cell viability was assessed using MTT assay, and the PAB was evaluated with the ELISA at $540 \mathrm{~nm}$. Catalase level was also evaluated in all groups. Furtheremore, the expression of KEAP1/Nrf2 genes was assessed using qRT-PCR. The results showed a significant reduction in L6 cells survival after being treated with $100 \mu \mathrm{M}$ BPA. Adiponectin and quercetin treatment also increased cell survival compared to BPA-treated cells. It was also found that PAB increased with BPA exposure, and quercetin treatment significantly reduced it compared to BPA treatment. The catalase activity was reduced in BPA-treated cells, which was significantly increased by treatment with adiponectin and quercetin. A significant decrease in Nrf2 gene expression was observed in BPA-treated cells compared to the control group. It was further found that cell treatment with quercetin and adiponectin significantly increased the expression of $\mathrm{Nrf} 2$ gene compared to the control group.

Conclusions: Taking together, our results implied that adiponectin and quercetin could modulate BPAinduced oxidative stress in muscle cells through KEAP1/Nrf2 pathway. Accordingly, it can be concluded that adiponectin in low dose and quercetin, may have significant impact in reducing toxicity due to BPA.

\section{Introduction}

In the last decade, environmental estrogenic compounds such as bisphenol A (BPA) have raised public health concerns due to their adverse effects in animal models (1). BPA, a potential endocrine-disrupting chemical, is used in factories producing polycarbonate plastics, epoxy resins, food packaging and coating, rubber chemicals, and dental sealants (2). Human studies suggest that BPA may be associated with type 2 diabetes and cardiovascular disease. Recent studies have shown that oxidative stress induced by BPA can lead to insulin resistance (3). Previous studies have shown that BPA exerts diabetogenic effects by diverting insulin signaling to skeletal muscle and adipose tissue. BPA may counteract its toxic effects by increasing oxidative stress and decreasing levels of antioxidants (4).

Cellular metabolism leads to the continuous production of reactive oxygen species (ROS), such as superoxide radicals or non-radical hydrogen peroxide. The imbalance between reactive oxygen species and antioxidant defense mechanisms in a cell leads to oxidative stress emerging (5). Evidence shows that cell damage caused by oxidative stress is involved in the pathogenesis of more than a hundred diseases (6). ROS are produced in skeletal muscle both at rest and during contractile activity. Besides, it 
has been reported that oxidative stress plays a crucial role in muscle cell pathology through multiple routes including, mitochondrial dysfunction, increased ubiquitin-proteasome system activity, increased myonuclear apoptosis, decreased protein synthesis pathway, and deregulated autophagy. These conditions finally lead to cachexia-skeletal muscle atrophy (7). Myogenic cells are equipped with antioxidant enzymes such as superoxide dismutase, catalase, glutathione peroxidase, and Heme oxygenase 1 . They affect the viability and proliferation of muscle satellite cells and affect the differentiation of myoblasts (5).

On the other hand, flavonoids such as quercetin delay cell death and oxidative damage by scavenging free radicals (8). Previous studies have shown that quercetin up to $100 \mathrm{mg}$ per day is well tolerated in humans and has no side effects or harmful physiological effects. Moreover, it effectively reduces the risk of cardiovascular disease by reducing oxidative stress (9). Meanwhile, studies have revealed that quercetin, as a powerful antioxidant, concerted its antioxidant effects in the presence of high levels of oxidative stress. Quercetin is able to inhibit oxidant biomolecules that can alter antioxidant defense pathways in vivo and in vitro $(10,11)$. Another powerful antioxidant can be attributed to adiponectin . Adiponectin is an endocrine factor that is expressly released from adipose tissue and suppresses the harmful effects of oxidative stress (12). Adiponectin exerts protective effects on heart tissue against oxidative stress induced by the remodeling process in cardiomyocytes by activating AMP-activated protein kinase (AMPK) and inhibiting regulatory kinases with extracellular signals and the NF-KB pathway (13).

To cope with stressful conditions, mammalian cells have developed complex defense mechanisms to adapt to these conditions, including the Keap1 / Nrf2 pathway (14). Under stress-free conditions, Nrf2 (nuclear factor erythroid 2-related factor 2) binds to the KAEP1 (Kelch-like ECH-associated protein 1) protein in the cytosol. It is ubiquitinated and degraded after a few hours. During cellular stress, several cysteine amino acids are oxidized or covalently oxidized to alter KAEP1 conformity. By the conformation change, Nrf2 is separated from KEAP1 and transported to the nucleus. It will bind to the ARE promoter region, leading to specific gene expression that causes increased cellular resistance to various stresses $(15,16)$.

Considering the inevitability of human exposure to BPA in current societies and its related health issues, this study aimed to investigate the effect of flavonoids quercetin and adiponectin on oxidative stress exerted by BPA on L6 cells (Rat skeletal muscle myoblast) through the KEAP1 / Nrf2 pathway.

\section{Materials And Methods}

\section{Experimental design}

An interventional study was performed on L6 (Rat skeletal muscle myoblast) cell line, purchased from Pasteur Institute, Iran. The BPA (Merck, Germany), adiponectin (Abnova, Taiwan), and quercetin (Sigma, 
USA) were purchased and prepared in different concentrations. The cells were divided into the following groups:

1. Cells with no treatment as the control group

2. Cells treated with BPA (50 and $100 \mu \mathrm{M})$

3. Cells treated with BPA (50 and $100 \mu \mathrm{M})$ and quercetin (10 and $25 \mathrm{ng} / \mathrm{ml}$ )

4. Cells treated with BPA (50 and $100 \mu \mathrm{M})$ and adiponectin ( 10 and $100 \mathrm{ng} / \mathrm{ml})$

5. Cells treated with BPA (50 and $100 \mu \mathrm{M}$ ), quercetin (10 and $25 \mathrm{ng} / \mathrm{ml}$ ), and adiponectin (10 and 100 $\mathrm{ng} / \mathrm{ml}$ )

\section{Mtt Assay}

The L6 cells were cultured in DMEM medium supplemented with $10 \%$ FBS (Gibco) to reach suitable confluency. 7000 cells were cultured into 96 wells plate. $24 \mathrm{~h}$ later, each medium was replaced by the prepared mediums containing BPA, quercetin, and adiponectin according to the mentioned groups. 24 and $48 \mathrm{~h}$ after treatment, cells were incubated with (3-(4,5-dimethylthiazol-2-yl)-2,5-diphenyltetrazolium bromide) MTT solution ( $5 \mathrm{mg} / \mathrm{ml}$ of DMEM) for $3 \mathrm{~h}$. Next, the supernatant was taken away, and DMSO solvent was added. The absorbance of suspension was then read at $570 \mathrm{~nm}$ using a microplate reader.

\section{Prooxidant-antioxidant Balance (Pab) Assay}

The PAB test has been performed in two different reactions, including enzymatic and chemical reactions. In the enzymatic reaction, the pro-oxidants oxidize the chromogen TMB to a color cation, while in the chemical reaction, the antioxidants reduce the TMB cation to a colorless compound. First, by dissolving the TMB powder in DMSO, the TMB/DMSO solution was prepared. Next, $1 \mathrm{ml}$ of TMB/DMSO solution was added to acetate buffer $(50 \mathrm{~mL}, \mathrm{pH} 4.5)$. Then, chloramine $\mathrm{T}(175 \mu \mathrm{L}, 100 \mathrm{mM})$ to prepare the TMB cation solution incubated in a dark place for 2 hours at room temperature. Also, $16.5 \mu \mathrm{L}$ of peroxidase enzyme solution was added and placed at $-20^{\circ} \mathrm{C}$.

TMB solution was prepared by adding $200 \mu \mathrm{L}$ of TMB/DMSO to the acetate buffer ( $10 \mathrm{~mL}, \mathrm{pH} 5.6)$. As the working solution, the third solution was prepared by adding $1 \mathrm{ml}$ of TMB cation solution to $10 \mathrm{ml}$ of TMB solution and, after 6 min incubation in the dark place at room temperature, freshly used. Also, the standard solutions are obtained by mixing different ratios of hydrogen peroxide at a concentration of 500 $\mu \mathrm{M}$ (as peroxidants) with a solution of $3 \mathrm{mM}$ Uric acid in $10 \mathrm{mM} \mathrm{NaOH}$ (as antioxidants).

To perform the PAB test and evaluate the oxidant and antioxidant activity of the cells, 50,000 cells were cultured in 24 well plates according to the mentioned groups for 24 and 48 h. $200 \mu \mathrm{L}$ of the working solution was added to each well and incubated in a dark place at $37^{\circ} \mathrm{C}$ for $12 \mathrm{~min}$. Then, $5 \mu \mathrm{L}$ of HCL $2 \mathrm{~N}$ was added to wells, and the optical density (OD) was read at $450 \mathrm{~nm}$ (the reference wavelength was 620 $\mathrm{nm})$. 


\section{Catalase Activity Assay}

For catalase activity evaluation, hydrogen peroxide, and ammonium molybdate solutions were prepared. Briefly, $102 \mu$ of $30 \%$ hydrogen peroxide solution (Mw: $34.01,9.79 \mathrm{~N}$ ) was diluted with PBS to $50 \mathrm{ml}$, and $10 \mathrm{~g}$ of ammonium molybdate was diluted to $250 \mathrm{ml}$ with distilled water to prepare $20 \mathrm{mM}$ hydrogen peroxide solution and $32.4 \mathrm{mM}$ ammonium molybdate, respectively. Different catalase reagents were designed and are shown in Table 1.

Table 1

Preparation of catalase reagents

\begin{tabular}{|lllll|}
\hline Reagent & Test & Control test & Standard & Blank \\
\hline Serum & $100 \mu \mathrm{l}$ & $100 \mu \mathrm{l}$ & - & - \\
\hline Distilled water & - & $1000 \mu \mathrm{l}$ & $100 \mu \mathrm{l}$ & $1100 \mu \mathrm{l}$ \\
\hline hydrogen peroxide & $1000 \mu \mathrm{l}$ & - & $1000 \mu \mathrm{l}$ & - \\
\hline
\end{tabular}

The reagents were gently mixed with the vortex. After incubation at $37^{\circ} \mathrm{C}$ for 3 minutes, $4 \mathrm{ml}$ of ammonium molybdate was added to the tubes and read at $374 \mathrm{~nm}$ using a spectrophotometer. Formula 1 is used to obtain the activity of the catalase enzyme based on (KU / L) KU.

$$
\text { Catalaseactivity }=2.303 / t \times(\log (S .) /(S-M)) \times V T / V S
$$

Formula 1. Calculating catalase activity, in which t: time, VT: Total volume of test tube reagents, S『: Standard absorption, S: Sample absorption, VS: Test sample volume

\section{Qrt-pcr}

L6 cells were cultured and treated with BPA, adiponectin, and quercetin for $24 \mathrm{~h}$. According to the protocol instruction, the total RNA was extracted using the trizol Reagent (Total RNA Isolation Reagent) according to the protocol instruction. The purity and amount of RNA were measured by NanoDrop 2000c (Thermo Scientific, Pittsburgh, PA, USA). Complementary DNA (cDNA) was synthesized using cDNA synthesis kit (Yektatajhiz, Co, Iran) according to the instruction. RealQ Plus 2x Master Mix green was used for realtime PCR analysis based on its instruction. RTqPCR was done using Applied Biosystems Real-Time PCR Instrument. Primers for GAPDH: the housekeeping gene, Nrf2, and KEAP1 genes, are shown in Table 2. Real time-PCR was performed by the 10-min at $95^{\circ} \mathrm{C}$ for enzyme activation, followed by 35 cycles of 15 seconds for denaturation at $95^{\circ} \mathrm{C}, 60$ seconds for annealing at $54.5^{\circ} \mathrm{C}$, and 25 seconds for the extension at $72^{\circ} \mathrm{C}$. The $2^{-\Delta \Delta C t}$ method was used to calculate relative expression levels. 
Table 2

Specific primers for evaluated genes

\begin{tabular}{|c|c|c|c|c|}
\hline Primers & & Sequans & Size (bp) & $\mathrm{Tm}$ \\
\hline \multirow[t]{2}{*}{ GAPDH } & forward & TGACTGTGCCGTTGAACTTG & 224 & $54.5^{\circ} \mathrm{C}$ \\
\hline & reverse & GAGACAGCCGCATCTTCTTG & & \\
\hline \multirow[t]{2}{*}{ Keap1 } & forward & CAGCGTGGAGAGATATGAG & 158 & $57^{\circ} \mathrm{C}$ \\
\hline & reverse & AGTAACATTCTGCCGAGTT & & $53^{\circ} \mathrm{C}$ \\
\hline \multirow[t]{2}{*}{ Nrf2 } & forward & ACAACTGGATGAAGAGACCG & 101 & $58^{\circ} \mathrm{C}$ \\
\hline & reverse & TGTGGGCAACCTGGGAGTAG & & $63^{\circ} \mathrm{C}$ \\
\hline
\end{tabular}

\section{Results}

\section{MTT assay}

L6 cells viability in the presence of BPA ( 50 and $100 \mu \mathrm{M})$ before and after treatment with adiponectin and quercetin was evaluated using MTT assay, and the results are shown in Figure 1. Based on the results, 50 $\mu \mathrm{M}$ BPA had no significant effect on L6 cells viability after 24 hours. The results also showed that the viability of L6 cells treated with $50 \mu \mathrm{M}$ BPA in the presence of adiponectin (A) $10 \mathrm{ng} / \mathrm{ml}$ and $100 \mathrm{ng} / \mathrm{ml}$, quercetin (Q) $10 \mathrm{ng} / \mathrm{ml}$ and $25 \mathrm{ng} / \mathrm{ml}$, after 24 hours was not significantly different from the control group (Figure 1A).

After 48 hours of L6 cells treatment with the mentioned groups, the results showed that only BPA ( $50 \mu \mathrm{M})$ $+A(100 \mathrm{ng} / \mathrm{ml})$ significantly reduced the cells' survival compared to the control group $(p<0.05)$ (Figure1B).

Also, according to the results shown in Figure $1 \mathrm{C}$, it was found that BPA $(100 \mu \mathrm{M})$ led to no significant effect on cell survival in any A and Q treatments after 24 hours.

After 48 hours of L6 cells treatment with BPA $(100 \mu \mathrm{M})$, it was found that the cells survival in BPA (100 $\mu \mathrm{M})$, BPA $(100 \mu \mathrm{M})+\mathrm{A}(10 \mathrm{ng} / \mathrm{ml})$, and BPA $(100 \mu \mathrm{M})+\mathrm{A}(100 \mathrm{ng} / \mathrm{ml})$ had significantly decreased compared to the control group $(p<0.05)$ (Figure 1D).

\section{Investigation Of Catalase Activity}

The catalase activity of L6 cells was examined and the results are shown in Figure 2 . The results showed that the presence of BPA decreased the catalase activity of L6 cells in all treated groups. But Q $(25 \mathrm{ng} / \mathrm{ml})$ and $A(10 \mathrm{ng} / \mathrm{ml})$ along with $\mathrm{Q}(25 \mathrm{ng} / \mathrm{ml})$ had opposite effects on BPA impact. (Figure 2A). 
The toxic effect of BPA on catalase activity also was seen after $48 \mathrm{~h}$. In this situation, Q $(25 \mathrm{ng} / \mathrm{ml})$ and A (10 ng/ml) with Q $(10,25 \mathrm{ng} / \mathrm{ml}$ ) relieved BPA effect (Figure 2B).

L6 catalase activity after 24 hours of treatment with $100 \mu \mathrm{M}$ BPA in all groups was significantly reduced compared to the control group $(\mathrm{p}<0.05)$ (Figure $2 \mathrm{C}$ ). Frthermore, 48 hours after treatment, all groups demonstrated significant catalase activity decline than control group $(p<0.05)$ exept, BPA $(100 \mu M)+A$ $(10 \mathrm{ng} / \mathrm{ml})+\mathrm{Q}(10,25 \mathrm{ng} / \mathrm{ml})(\mathrm{p}<0.05)($ Figure $2 \mathrm{D})$.

Figure 2 evaluation of catalase activity. (A) L6 cells catalase activity with $50 \mu \mathrm{M}$ BPA in the presence of adiponectin (A) and quercetin (Q) after $24 \mathrm{~h}$. (B) L6 catalase activity treated with $50 \mu \mathrm{M}$ BPA in the presence of $(A)$ and, $(Q)$ after 48 hours. (C) L6 cells catalase activity treated with $100 \mu M$ BPA in the presence of $(A)$ and $(Q)$ after $24 \mathrm{~h}$ and (D) L6 cells catalase activity treated with $100 \mu \mathrm{M}$ BPA in the presence of $(A)$ and $(Q)$ after $48 \mathrm{~h}$. Data expressed as mean $\pm S D$. * Present significant difference at $P \leq$ 0.05 compared to control.

\section{Measurement Of Prooxidant-antioxidant (Pab) Balance}

The results of the PAB analysis of BPA-treated L6 cells (50 and $100 \mu \mathrm{M})$ in the presence of adiponectin and quercetin are shown in Figure 3 . The results showed that 24 hours after cell treatment with BPA 50 $\mu \mathrm{M}, \mathrm{PAB}$ had a significant increase compared to the control group $(\mathrm{p}<0.05)$. According to the results, presence of Adiponectin in high concentration, showed a significant increase in PAB compared to the control group $(p<0.05)$ (Figure $3 A)$. The minimum amount of PAB was seen in $A(10 \mathrm{ng} / \mathrm{ml})$ with $Q(25$ $\mathrm{ng} / \mathrm{ml})$.

$50 \mu \mathrm{M}$ BPA leads to significant increase in PAB compared to the control group after $48 \mathrm{~h}(\mathrm{p}<0.05)$. Also a combination of BPA $(50 \mu \mathrm{M})+\mathrm{A}(10 \mathrm{ng} / \mathrm{ml})$, BPA $(50 \mu \mathrm{M})+\mathrm{A}(100 \mathrm{ng} / \mathrm{ml}), \mathrm{BPA}(50 \mu \mathrm{M})+\mathrm{A}(100 \mathrm{ng} / \mathrm{ml})$ $+\mathrm{Q}(10 \mathrm{ng} / \mathrm{ml})$ and BPA $(50 \mu \mathrm{M})+\mathrm{A}(100 \mathrm{ng} / \mathrm{ml})+\mathrm{Q}(25 \mathrm{ng} / \mathrm{ml})$ also showed a significant increase in $P A B$ compared to the control group $(p<0.05)$ (Figure $3 B$ ). The maximum amount of PAB was seen in $A$ (100ng/ml).

Regarding $100 \mu \mathrm{M}$ BPA, the results after 24 and 48 hours showed that the PAB value of all treatments except BPA $(100 \mu \mathrm{M})+\mathrm{A}(10 \mathrm{ng} / \mathrm{ml})$ with Q $(25 \mathrm{ng} / \mathrm{ml})$ was significantly increased compared to the control group $(p<0.05)$ (Figure $3 \mathrm{C}$ and $\mathrm{D})$.

Figure 3 investigation of PAB. (A) L6 PAB treated with $50 \mu \mathrm{M}$ BPA in the presence of adiponectin (A) and quercetin (Q) after $24 \mathrm{~h}$. (B) L6 PAB treated with $50 \mu \mathrm{M} B P A$ in the presence of (A) and, (Q) after $48 \mathrm{~h}$. (C) ) L6 PAB treated with $100 \mu \mathrm{M}$ BPA in the presence of (A) and (Q) after $24 \mathrm{~h}$ and (D) L6 PAB treated with 100 $\mu \mathrm{M} B P A$ in the presence of $(A)$ and $(Q)$ after $48 \mathrm{~h}$. Data expressed as mean \pm SD. * Present significant difference at $P \leq 0.05$ compared to control.

\section{Investigation Of Keap1 And Nrf2 Gene Expression}


The expression of KEAP1 and Nrf2 genes in L6 cells was examined after treatment with BPA (50 and 100 $\mu \mathrm{M})$ and in the presence of different concentrations of adiponectin and quercetin, and the results are shown in Figure 4. The results showed that the expression of the KEAP1 gene treated with $50 \mu \mathrm{M}$ BPA had a significant increase only in BPA $(50 \mu \mathrm{M})+A(100 \mathrm{ng} / \mathrm{ml})$ group compared to the control group $(\mathrm{p}$ $<0.05)$ (Figure 4A). Nrf2 gene expression in BPA $(50 \mu \mathrm{M})+\mathrm{Q}(25 \mathrm{ng} / \mathrm{ml})$ and BPA $(50 \mu \mathrm{M})+\mathrm{A}(10 \mathrm{ng} / \mathrm{ml})$ with $Q(25 \mathrm{ng} / \mathrm{ml})$ groups was significantly higher than the control group $(p<0.05)$ (Figure 4B).

However, cells with BPA $(100 \mu \mathrm{M})$, BPA $(100 \mu \mathrm{M})+\mathrm{A}(10 \mathrm{ng} / \mathrm{ml})$, BPA $(100 \mu \mathrm{M})+\mathrm{A}(100 \mathrm{ng} / \mathrm{ml})$ and BPA $(100 \mu \mathrm{M})+\mathrm{A}(100 \mathrm{ng} / \mathrm{ml})$ with $\mathrm{Q}(25 \mathrm{ng} / \mathrm{ml})$ showed higher expression of KEAP1 gene than control group $(p<0.05)$ (Figure $4 \mathrm{C})$. Nevertheless, obvious differences were observed in the expression of KEAP1 gene in cells treated with $100 \mu \mathrm{M}$ BPA. The results showed that in BPA $(100 \mu \mathrm{M}), \mathrm{BPA}(100 \mu \mathrm{M})+\mathrm{A}(100$ $\mathrm{ng} / \mathrm{ml})$, and BPA $(100 \mu \mathrm{M})+\mathrm{Q}(10 \mathrm{ng} / \mathrm{ml}) \mathrm{Nrf2}$ expression was significantly reduced compared to the control group $(p<0.05)$ (Figure $4 \mathrm{D})$.

Figure $4(\mathrm{~A})$ Expression of the KEAP1 gene in L6 treated with $50 \mu \mathrm{M}$ BPA in the presence of adiponectin $(A)$ and quercetin (Q). (B) expression of NRF2 gene in L6 cells treated with BPA $50 \mu \mathrm{M}$ in the presence of (A) and, (Q). (C) expression of KEAP1 gene in L6 cells treated with BPA $100 \mu \mathrm{M}$ in the presence of (A) and (Q). (D) the expression of Nrf2 gene in L6 treated with $100 \mu \mathrm{M}$ BPA in the presence of (A) and (Q). Data expressed as mean \pm SD. * Present significant difference at $P \leq 0.05$ compared to control.

\section{Discussion}

The potential role of oxidants such as environmentally toxic compound in the pathogenesis of many diseases suggests that antioxidants may be an optimal option for encountering them. The ROS produced can disrupt metabolic regulation and enhance metabolic diseases such as insulin resistance locally in adipose tissue and insulin target tissues such as skeletal muscle and liver (17). Flavonoids, such as quercetin, can postpone cell death and oxidative damage through free radical scavenging. Quercetin can improve the body's metabolism through ROS uptake (18-21). According to previous studies, adiponectin plays a protective role in the metabolism of many body tissues, including heart tissue, skeletal muscle, liver tissue, and adipose tissue through reducing ROS levels $(22,23)$.

Based on the results of our study, the toxicity effect of BPA on L6 cells was dependent on concentration and time. $50 \mu \mathrm{M}$ BPA did not have any significant impact on cell viability for up to 48 hours. On the other hand, while $100 \mu \mathrm{M}$ did not show any toxicity on the cells for 24 hours, it significantly reduced cells survival after 48 hours. Increased BPA concentrations are associated with an increased risk of cardiovascular, hepatic, and renal diseases such as coronary heart disease, fatty liver disease, and chronic kidney disease. In this regard, BPA has been shown to cause various cytotoxic, genotoxic, and carcinogenic effects in vitro and in vivo. In line with our findings, Podlich et al. studied the cytotoxic effects of BPA on HEK293 cells. They showed that incubation of HEK293 with $100 \mu \mathrm{M}$ or $1000 \mu \mathrm{M}$ BPA resulted in a significant dose-dependent reduction in renal cell viability (24). Moreover, BPA-treated cells incubated with adiponectin and quercetin showed that treatments with quercetin (at both concentrations) 
were able to overcome BPA-induced toxicity after 48 hours. Sangai NP et al. showed that quercetin decreased ROS production and increased total antioxidant capacity in rat kidneys (25). The use of quercetin can reduce the production of free radicals and play an essential role in improving the antioxidant/oxidant balance (26). However, quercetin has another therapeutic property that inhibits lipid peroxidation and has been shown to inhibit $\mathrm{H}_{2} \mathrm{O}_{2}$-induced lipid peroxidation even at a low concentration $(2 \mu \mathrm{M})(27)$.

Catalase activity was also evaluated in our study, and the results showed that cell treatment with BPA at both 50 and $100 \mu \mathrm{M}$ significantly reduced the cells' catalase activity at 24 and 48 hours. Shirani et al. also showed that BPA reduced catalytic activity in all rats (28). In another study, Aboul Ezz et al. Reported similar results for BPA-treated rats after six weeks (27). Catalase is an enzyme found in almost all living organisms exposed to oxygen that catalyzes the breakdown of hydrogen peroxide into water and oxygen. This enzyme is crucial in protecting cells against oxidative damage by ROS. Our study showed that quercetin is almost more compelling than adiponectin in increasing cell catalase. Shirani et al. had reported similar results on the effect of quercetin on catalase activity (28). Demkovych et al. also reported increased catalytic activity due to quercetin treatment in rats (29).

PAB was evaluated in BPA-treated cells. The results showed that BPA at both concentrations significantly increased PAB. BPA disrupts cellular oxidative homeostasis by altering the dynamic balance between oxidative mediators and the activity of antioxidant enzymes, thereby predisposing the cell to apoptosis (30). Moghaddam et al. Reported that exposure to BPA ( 0.5 and $2 \mathrm{mg} / \mathrm{kg} /$ day) for four weeks in male mice significantly disrupted the dynamic balance of enzymatic antioxidants (31). Regardless of the presence of the antioxidant system, excessive or unbalanced production of ROS due to exposure to chemicals may lead to several clinical disorders. For example, BPA can cause oxidative stress by disrupting the oxidation state of cells (32). Therefore, our study confirmed that BPA exposure induced oxidative stress by upsetting the balance between ROS and the antioxidant defense system in L6 cells. Our results also showed that quercetin reduced the effects of BPA on PAB. It seems that the use of compounds with potent antioxidant properties such as quercetin can reduce the production of free radicals due to BPA toxicity in the body and play an essential role in improving the antioxidant/oxidant balance (33). In a study, Mahdavinia et al. examined the effect of quercetin on the oxidative toxicity of BPA in the liver. They reported that potential hepatotoxicity of BPA could be prevented with quercetin, which protects the body against oxidative stress (33).

In this study, we also investigated the expression of KEAP1 and Nrf2 genes and found that BPA at 100 $\mu \mathrm{M}$ concentration increased KEAP1 expression and decreased Nrf2 expression. Nrf2 is a transcription factor that mediates an essential signaling pathway that prevents injury and disease. Under normal circumstances, Nrf2 is found and degraded in the cytoplasm attached to KEAP1. Following oxidative stress or drug intervention, Nrf2 is cleaved from KEAP1 and transported to the nucleus, activating transcription of protective genes to defend against organ damage (34). Our results found that BPA in L6 cells causes oxidative stress by activating KEAP1 and suppressing Nrf2. Similar results were reported by Zhangshan Gao et al. Regarding the effect of BPA on laying hens and acknowledged that BPA leads to 
disrupt ovarian redox homeostasis by activating Keap1 and suppressing the Nrf2 signaling pathway (35). Our study showed that the combination of quercetin $(25 \mathrm{ng} / \mathrm{ml})$ and adiponectin $(10 \mathrm{ng} / \mathrm{ml})$ could increase Nrf2 expression to normal level. In a parallel study, Li-LiJi et al. investigated the effect of quercetin on Nrf2 pathway expression in hepatotoxicity toxicity. They showed that quercetin increased the expression of Nrf2-dependent antioxidant genes through inhibition of Keap1binding to Nrf2 and inducing p62 expression (36). In another study, Ghazizadeh Darband et al. showed that quercetin reduced oxidative DNA damage through the Nrf2 signaling pathway in rats with colorectal cancer (37).

\section{Conclusion}

Due to the role of BPA in metabolic disorders, this study aimed to evaluate adiponectin and quercetin in reducing BPA-induced oxidative stress by assessing the PAB, catalase activity, and KEAP1/Nrf2 in muscle cells. The results showed that BPA decreased L6 cells viability in a dose-dependence and time-dependent manner and disrupted the catalase activity of cells. Further, it was found that quercetin and adiponectin increased cell survival and improved cell catalase activity. Similar results were found for PAB. It was also shown that BPA decreased Nrf2 expression and increased KEAP1 expression, which returned to the normal level with quercetin and adiponectin treatments. In conclusion, quercetin and adiponectin are increasingly looked upon as a support against toxic compounds, although additional clinical investigations are needed to be accomplished to prove the effectiveness and safety of adiponectin and quercetin.

\section{Declarations}

\section{Ethics approval and consent to participate}

The study was approved by the Deputy of Research and Technology and Ethics Committee of Zanjan University of Medical Sciences (Ethic Code: IR.ZUMS.RES.1399.021). Ethical considerations were considered at all stages of the research.

\section{Author Contribution}

$\mathrm{DM}$ and $\mathrm{MH}$ make substantial contributions to conception and design. FJM, DGh,KN and ZR participate in drafting the article or revising it critically for important intellectual content. All authors give final approval of the version to be submitted and any revised version.

\section{Acknowledgments}

This investigation was supported by Vice Chancellor for Research, Zanjan University of Medical Sciences.

\section{Conflicts of interest}

There are no conflicts of interest. 
Availability of data and materials

The data supporting findings of this study are available on request from the corresponding author. The data are not publicly available due to privacy or ethical restrictions.

\section{References}

1. Carwile JL, Michels, KBJEr (2011) Urinary bisphenol A and obesity: NHANES 2003-2006. Environ Res 111(6):825-830

2. Groff TJCoip (2010) Bisphenol A: invisible pollution. Curr Opin Pediatr 22(4):524-529

3. Song S, Zhang L, Zhang H, Wei W (2014) Jia LJljoer, health p. Perinatal BPA exposure induces hyperglycemia, oxidative stress and decreased adiponectin production in later life of male rat offspring. Int J Environ Res Public Health 11(4):3728-3742

4. Alonso-Magdalena P, Ropero AB, Soriano S, Quesada I, Nadal AJH (factor? 2010) Bisphenol-A: a new diabetogenic. 9:118-1262

5. Kozakowska M, Pietraszek-Gremplewicz K, Jozkowicz A, Dulak J (2015) The role of oxidative stress in skeletal muscle injury and regeneration: focus on antioxidant enzymes. J Muscle Res Cell Motil 36(6):377-393

6. Maritim A, Sanders a, Watkins lii J (2003) Diabetes, oxidative stress, and antioxidants: a review. J Biochem Mol Toxicol 17(1):24-38

7. Ábrigo J, Elorza AA, Riedel CA, Vilos C, Simon F, Cabrera D et al (2018) Role of Oxidative Stress as Key Regulator of Muscle Wasting during Cachexia. Oxidative Med Cell Longev 2018:2063179

8. Xu D, Hu M-J, Wang Y-Q, Cui Y-LJM (2019) Antioxidant activities of quercetin and its complexes for medicinal application. 24:11236

9. Morand C, Crespy V, Manach C, Besson C, Demigne C, Remesy CJAJoP-R, Integrative et al (1998) Plasma metabolites of quercetin and their antioxidant properties. American Journal of PhysiologyRegulatory, Integrative and Comparative Physiology 275(1):R212-R2R9

10. Song X, Wang Y, Gao LJJomm (2020) Mechanism of antioxidant properties of quercetin and quercetin-DNA complex. 26:1-8

11. Lesjak M, Beara I, Simin N, Pintać D, Majkić T, Bekvalac K et al (2018) Antioxidant and antiinflammatory activities of quercetin and its derivatives. 40:68-75

12. Straub LG, Scherer PEJNM (2019) Metabolic Messengers: adiponectin. Nature Metabolism 1(3):334

13. Essick EE, Ouchi N, Wilson RM, Ohashi K, Ghobrial J, Shibata R et al (2011) Adiponectin mediates cardioprotection in oxidative stress-induced cardiac myocyte remodeling. Am J Physiol Heart Circ Physiol 301(3):H984-HH93

14. Matzinger M, Fischhuber K, Heiss EH (2018) Activation of Nrf2 signaling by natural products-can it alleviate diabetes? Biotechnol Adv 36(6):1738-1767 
15. Suzuki T, Motohashi H, Yamamoto MJTips (2013) Toward clinical application of the Keap1-Nrf2 pathway. 34:340-3466

16. Baird L, Yamamoto MJM (2020) The molecular mechanisms regulating the KEAP1-NRF2 pathway. 40:e00099-e00020biology c13

17. Li Z, Chen B, Dong W, Xu W, Song M, Fang M et al (2018) Epigenetic activation of PERP transcription by MKL1 contributes to ROS-induced apoptosis in skeletal muscle cells. Biochimica et Biophysica Acta (BBA)-Gene Regulatory Mechanisms. 1861:905-9159

18. Rezaei-Sadabady R, Eidi A, Zarghami N, Barzegar A (2016) Intracellular ROS protection efficiency and free radical-scavenging activity of quercetin and quercetin-encapsulated liposomes. Artificial cells, nanomedicine, and biotechnology 44(1):128-134

19. Chen T-J, Jeng J-Y, Lin C-W, Wu C-Y, Chen Y-C (2006) Quercetin inhibition of ROS-dependent andindependent apoptosis in rat glioma C6 cells. Toxicology 223(1-2):113-126

20. Abharzanjani F, Hemmati M (2021) Protective effects of Quercetin and Resveratrol on aging markers in kidney under high glucose condition: in vivo and in vitro analysis. Mol Biol Rep 48(7):5435-5442

21. Aramjoo $\mathrm{H}$, Ebrahimzadeh $\mathrm{H}$, Hemmati $\mathrm{M}$ (2021) Investigation of protective effects of quercetin on Oxidative stress induced by Vinblastine in bone marrow of Rats.Pharmaceutical Sciences. 27:1942002

22. Karamian M, Moossavi M, Hemmati M (2021) From diabetes to renal aging: the therapeutic potential of adiponectin. J Physiol Biochem 77(2):205-214

23. Esfahani M, Movahedian A, Baranchi M, Goodarzi MT (2015) Adiponectin: an adipokine with protective features against metabolic syndrome. Iran J Basic Med Sci 18(5):430-442

24. Podlich SPC, Bohme K, Kreutz R, Leppert U et al (2018) Comparative Analysis of Cytotoxic Effects of Bisphenol A and Bisphenol S on Human Renal HEK293 Cells.Arch Sci; 2

25. Sangai NP, Verma RJ (2012) Protective effect of quercetin on bisphenol A-caused alterations in succinate dehydrogenase and adenosine triphosphatase activities in liver and kidney of mice. Acta Pol Pharm 69:1189-1194

26. Fartkhooni FM, Noori A, Mohammadi A (2016) Effects of titanium dioxide nanoparticles toxicity on the kidney of male rats. International Journal of Life Sciences 10(1):65-69

27. Abarikwu SO, Simple G, Onuoha SC, Mokwenye I, Ayogu J-F (2020) Evaluation of the protective effects of quercetin and gallic acid against oxidative toxicity in rat's kidney and HEK-293 cells. Toxicology Reports 7:955-962

28. Shirani M, Alizadeh S, Mahdavinia M, Dehghani MA (2019) The ameliorative effect of quercetin on bisphenol A-induced toxicity in mitochondria isolated from rats. Environ Sci Pollut Res 26(8):76887696

29. Demkovych A, Bondarenko Y, Hasiuk P (2019) Effects of quercetin on antioxidant potential in the experimental periodontitis development. Interventional Medicine and Applied Science Interventional Medicine and Applied Science 11(1):60-64 
30. Amjad S, Rahman MS, Pang M-G (2020) Role of Antioxidants in Alleviating Bisphenol A Toxicity. Biomolecules 10(8):1105

31. Moghaddam HS, Samarghandian S, Farkhondeh T (2015) Effect of bisphenol A on blood glucose, lipid profile and oxidative stress indices in adult male mice. Toxicol Mech Methods 25(7):507-513

32. Hassan ZK, Elobeid MA, Virk P, Omer SA, ElAmin M, Daghestani MH et al (2012) Bisphenol A induces hepatotoxicity through oxidative stress in rat model. Oxid Med Cell Longev 2012:194829

33. Mahdavinia M, Alizadeh S, Vanani AR, Dehghani MA, Shirani M, Alipour M et al (2019) Effects of quercetin on bisphenol A-induced mitochondrial toxicity in rat liver. Iranian journal of basic medical sciences 22(5):499

34. Wen X, Thorne G, Hu L, Joy MS, Aleksunes LM (2015) Activation of NRF2 Signaling in HEK293 Cells by a First-in-Class Direct KEAP1-NRF2 Inhibitor. J Biochem Mol Toxicol 29(6):261-266

35. Gao Z, Gao X, Fan W, Liu S, Li M, Miao Y et al (2021) Bisphenol A and genistein have opposite effects on adult chicken ovary by acting on ERa/Nrf2-Keap1-signaling pathway. Chemico-Biol Interact 347:109616

36. Ji L-L, Sheng Y-C, Zheng Z-Y, Shi L, Wang Z-T (2015) The involvement of p62-Keap1-Nrf2 antioxidative signaling pathway and JNK in the protection of natural flavonoid quercetin against hepatotoxicity. Free Radic Biol Med 85:12-23

37. Darband SG, Sadighparvar S, Yousefı B, Kaviani M, Ghaderi-Pakdel F, Mihanfar A et al (2020) Quercetin attenuated oxidative DNA damage through NRF2 signaling pathway in rats with DMH induced colon carcinogenesis. Life Sci 253:117584

\section{Figures}

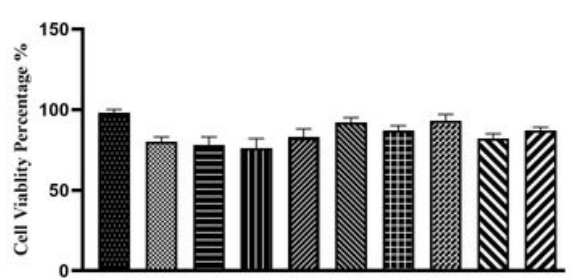

A

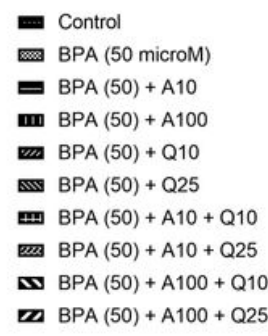

mPA $(50)+A 100+Q 25$
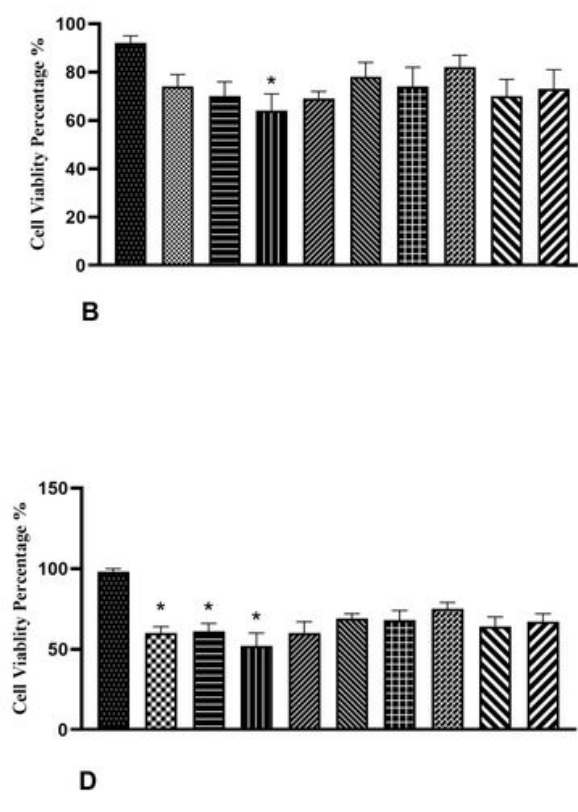

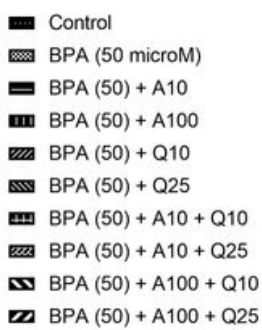

m. Control

m BPA (100 microm)

= BPA $(100)+\mathrm{A} 10$

m $\mathrm{BPA}(100)+\mathrm{A} 100$

mPA $(100)+Q 10$

BPA (100)+Q25

min $\mathrm{BPA}(100)+\mathrm{A} 10+\mathrm{Q} 10$

ख $B P A(100)+A 10+Q 25$

D $B P A(100)+A 100+Q 10$

m $\mathrm{BPA}(100)+\mathrm{A} 100+\mathrm{Q} 25$ 
Figure 1

investigation of cell viability by MTT assay. (A) L6 cells viability treated with $50 \mu \mathrm{M}$ BPA in the presence of adiponectin (A) and quercetin (Q) after $24 \mathrm{~h}$. (B) L6 cells viability treated with $50 \mu \mathrm{M}$ BPA in the presence of (A) and, (Q) after 48 hours. (C) ) L6 cells viability treated with $100 \mu \mathrm{M}$ BPA in the presence of $(A)$ and $(\mathrm{Q})$ after $24 \mathrm{~h}$ and (D) L6 cells viability treated with $100 \mu \mathrm{M}$ BPA in the presence of (A) and (Q) after $48 \mathrm{~h}$. Data expressed as mean \pm SD. * Present significant difference at $P \leq 0.05$ compared to control.
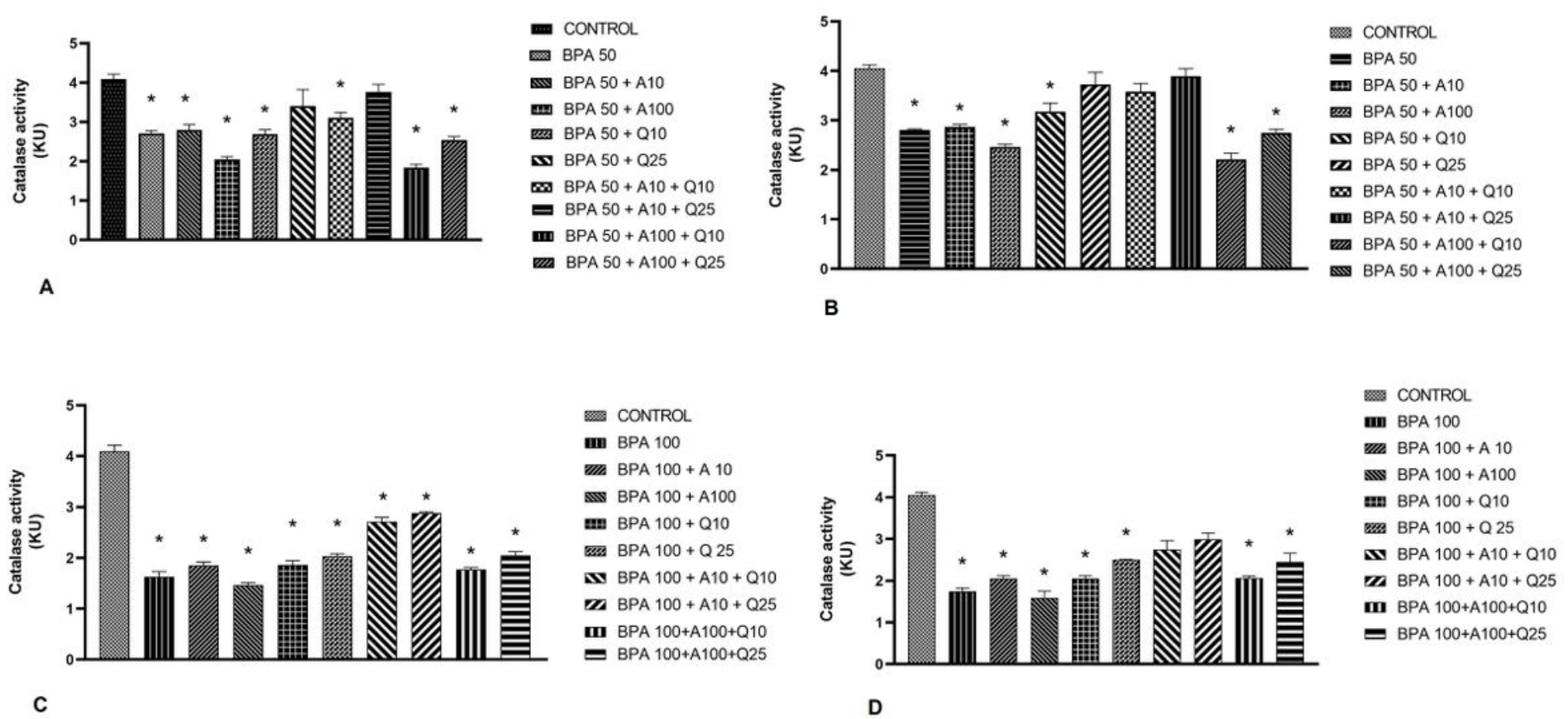

Figure 2

evaluation of catalase activity. (A) L6 cells catalase activity with $50 \mu \mathrm{M}$ BPA in the presence of adiponectin (A) and quercetin (Q) after $24 \mathrm{~h}$. (B) L6 catalase activity treated with $50 \mu \mathrm{M}$ BPA in the presence of $(A)$ and, $(Q)$ after 48 hours. (C) L6 cells catalase activity treated with $100 \mu \mathrm{M} B P A$ in the presence of $(A)$ and $(Q)$ after $24 \mathrm{~h}$ and (D) L6 cells catalase activity treated with $100 \mu \mathrm{M}$ BPA in the presence of $(A)$ and $(Q)$ after $48 \mathrm{~h}$. Data expressed as mean \pm SD. * Present significant difference at $P \leq$ 0.05 compared to control. 


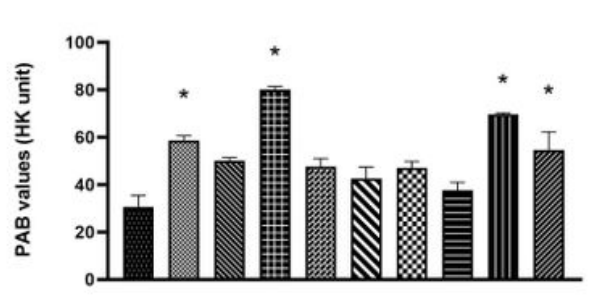

A

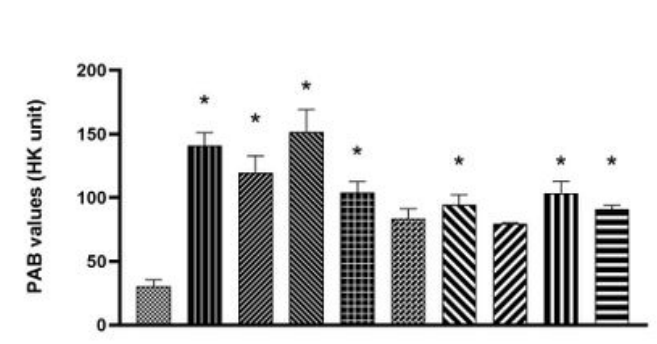

- . CONTROL

m BPA 100

IIA BPA $100+A 10$

ali BPA $100+A 100$

III BPA $100+Q 10$

BPA $100+Q 25$

a $\mathrm{BPA} 100+\mathrm{A} 10+\mathrm{Q} 10$

C. BPA $100+\mathrm{A} 10+\mathrm{Q} 25$

II BPA $100+A 100+Q 10$

= BPA $100+A 100+Q 25$

C

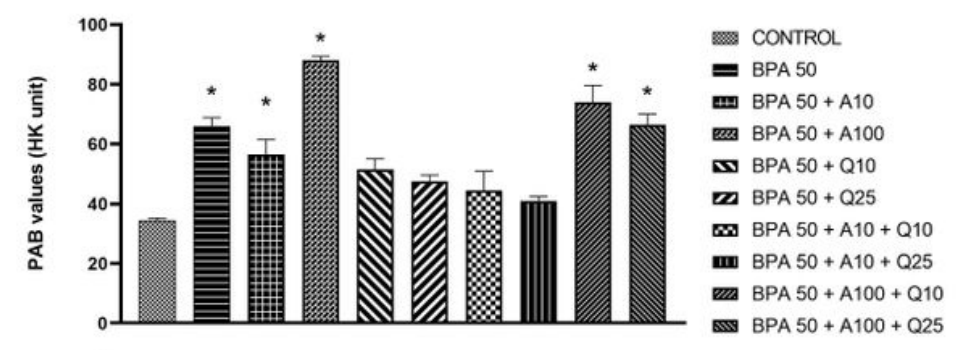

CONTROL

III BPA 100

III BPA $100+A 10$

ali BPA $100+A 100$

mII BPA $100+Q 10$

BPA $100+Q 25$

N $B P A 100+A 10+Q 10$

m BPA $100+\mathrm{A} 10+\mathrm{Q} 25$

II $B P A$ 100+A100+Q10

= BPA $100+\mathrm{A} 100+\mathrm{Q} 25$

Figure 3

investigation of PAB. (A) L6 PAB treated with $50 \mu \mathrm{M}$ BPA in the presence of adiponectin (A) and quercetin (Q) after $24 \mathrm{~h}$. (B) L6 PAB treated with $50 \mu \mathrm{M} B P A$ in the presence of (A) and, (Q) after $48 \mathrm{~h}$. (C) ) L6 PAB treated with $100 \mu \mathrm{M} B P A$ in the presence of $(A)$ and $(Q)$ after $24 \mathrm{~h}$ and (D) L6 PAB treated with $100 \mu \mathrm{M}$ BPA in the presence of $(A)$ and $(Q)$ after $48 \mathrm{~h}$. Data expressed as mean \pm SD. * Present significant difference at $\mathrm{P} \leq 0.05$ compared to control.
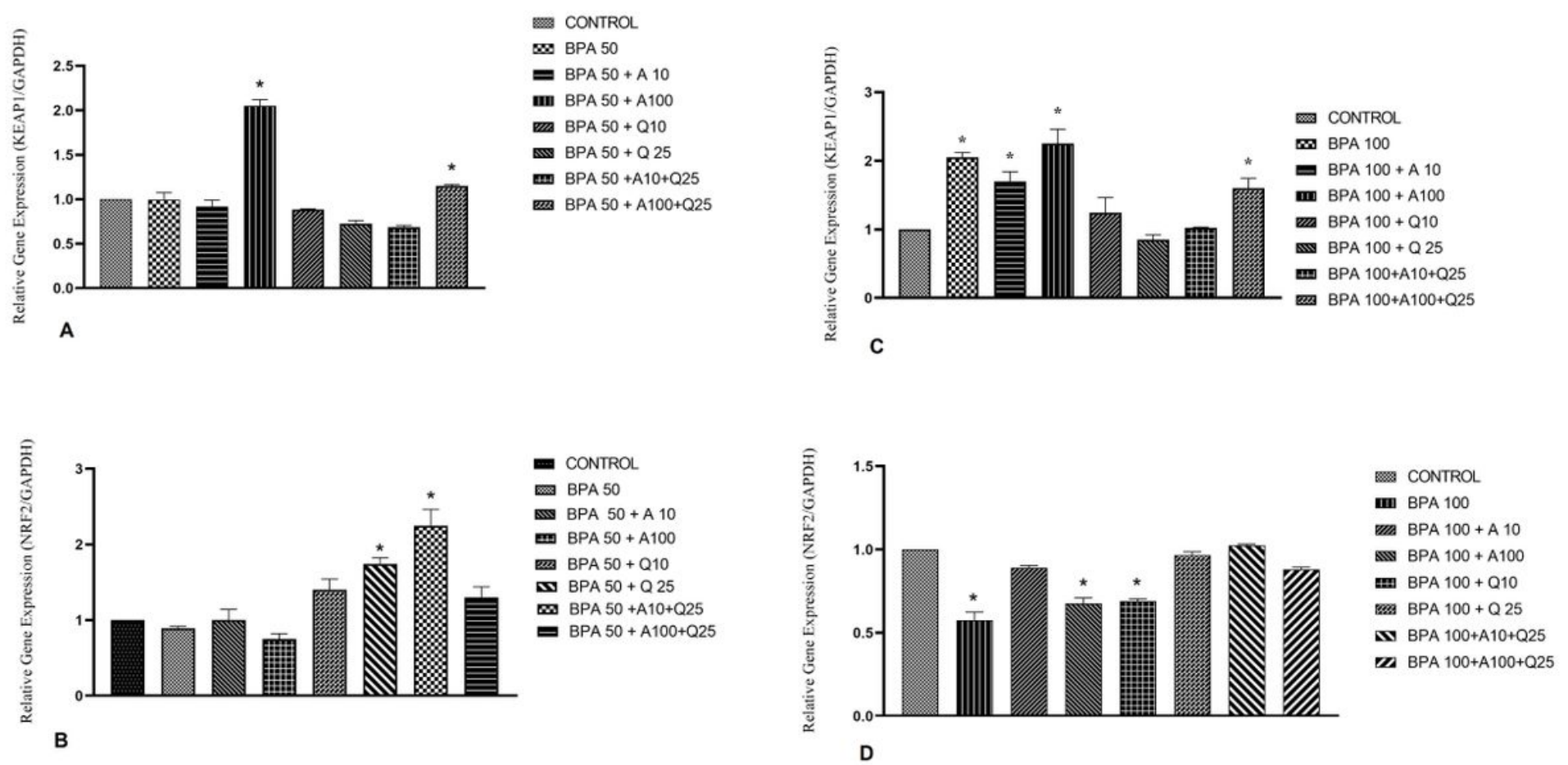

Figure 4 
(A) Expression of the KEAP1 gene in L6 treated with $50 \mu \mathrm{M}$ BPA in the presence of adiponectin $(A)$ and quercetin (Q). (B) expression of NRF2 gene in L6 cells treated with BPA $50 \mu \mathrm{M}$ in the presence of $(A)$ and, (Q). (C) expression of KEAP1 gene in L6 cells treated with BPA $100 \mu \mathrm{M}$ in the presence of (A) and (Q). (D) the expression of Nrf2 gene in L6 treated with $100 \mu \mathrm{M}$ BPA in the presence of (A) and (Q). Data expressed as mean $\pm \mathrm{SD}$. * Present significant difference at $\mathrm{P} \leq 0.05$ compared to control. 